\title{
Variability of drainage and solute leaching in heterogeneous urban vegetation environs
}

\author{
H. Nouri ${ }^{1}$, S. Beecham ${ }^{2}$, A. M. Hassanli ${ }^{3}$, and G. Ingleton ${ }^{4}$ \\ ${ }^{1}$ Centre for Water Management and Reuse, University of South Australia, Adelaide, 5095 SA, Australia \\ ${ }^{2}$ School of Natural and Built Environments, University of South Australia, Adelaide, 5095 SA, Australia \\ ${ }^{3}$ Shiraz University and Centre for Water Management and Reuse, University of South Australia, Adelaide, 5095 SA, Australia \\ ${ }^{4}$ Recycled Water in SA Water Corporation, Adelaide, 5095 SA, Australia
}

Correspondence to: H. Nouri (hamideh.nouri@unisa.edu.au, hamideh.nouri@mymail.unisa.edu.au)

Received: 13 May 2013 - Published in Hydrol. Earth Syst. Sci. Discuss.: 29 May 2013

Revised: 22 August 2013 - Accepted: 25 August 2013 - Published: 1 November 2013

\begin{abstract}
Deep percolation enhancement from recycled wastewater irrigation may contribute to salt accumulation and water table elevation that can ultimately cause soil and ground water degradation. Variation of drainage rate and solute leaching were investigated in an urban park containing heterogeneous landscape plants that were irrigated with recycled wastewater. Field monitoring was undertaken at Veale Gardens in the Adelaide Parklands, Australia. Based on landscape variation in Veale Gardens, two landscape zones were defined: one being largely covered with turf grasses with few trees and shrubs (MG) with the second zone being mostly trees and shrubs with intermittent turf grasses (MT). Experiments were performed on two zero-tension lysimeters placed horizontally $100 \mathrm{~cm}$ below ground to monitor the variation of volume and quality indicators of drained water for four seasons. The outcomes showed a significant variation of drainage quantity and quality in the MT and MG zones. The low vegetation cover in the MG zone resulted in more drained water than in the high vegetation cover (MT zone). In both zones, more drainage water was collected in winter than in other seasons. This is in spite of the input water showing a maximum rate in summer. The seasonal salinities measured in the two lysimeters showed very similar trends with the lowest salinity rate in autumn with the levels increasing through winter and spring. Chemical analyses of leachate solute and salt loading indicated no impact from using recycled wastewater.
\end{abstract}

\section{Introduction}

It is of interest to study drainage rates and solute transfers beyond the effective plant root zone since this can help in understanding the soil water balance status, availability of nutrients in the leachate as well as the risk of nutrient loading to the ground water.

Research evaluating drainage quantity and quality in urban mixed landscapes vegetation is limited. Insufficiencies and obstacles in understanding soil water conditions particularly in urban landscape environs undermine a sound judgement of urban soils (Jim, 1998; Jim and Chen, 2008; De Kimpe and Morel, 2000). Improving the knowledge of soil biochemical properties assists in understanding nutrient cycling in urban soils (Lorenz and Kandeler, 2005) and subsequently prevents either inadequate or excessive input applications, e.g. fertilization (Rosen et al., 2008). For instance, Lassaletta et al. (2012) concluded reducing surplus $\mathrm{N}$ fertilization as the most promising management system.

Appropriate interpretation of water and soil test results is subject to collecting representative water and soil samples. The choice of sampling method of drained water is of great importance. Several studies have been conducted in agriculture and forestry that may provide useful information for urban soil studies (Jim, 1998). The impact of available soil water sampling systems on vadose zone behaviour increases the uncertainty in selecting a representative sample (Peters and Durner, 2009). This is even more problematic in mixed vegetation urban green spaces (Nouri et al., 2012). High spatial and temporal variability of vegetation species, canopy covers 
and microclimates in urban landscape vegetation leads to a high variability of soil water characteristics and soil water accessibility. This introduces more complexity and uncertainty in quantification of drained water and nutrient leachate. Soil water sampling from undisturbed soil in a heterogeneous landscape environs with the purpose of systematic investigation of quantity and quality of drainage can be achieved by in situ soil water collectors. However, it should be noted that in situ sampling may not be spatially representative of a large area so the results are often restricted to small observation sites such as plots or small fields.

Investigation of nutrients in drained water has been undertaken since around 1850. A number of techniques and geometries of leachate collection devices have been tested and reviewed over recent decades (Hangen et al., 2005; MorenoJiménez et al., 2011; Parizek and Lane, 1970; Yoo, 2001; Weihermuller et al., 2007). The most common inexpensive approaches are soil coring, suction cup (Hagedorn et al., 1999), suction plate (Kosugi and Katsuyama, 2004), wick lysimeter (Jabro et al., 2008), and zero-tension plate lysimeter (Peters and Durner, 2009; Robison et al., 2004). These studies have demonstrated the importance of soil profile characteristics in determining the infiltration rate of irrigation and/or precipitation as well as nutrient mobilization. An undisturbed soil profile can retain the natural soil structure (Goss et al., 2010) but disturbed soil can introduce artificial soil properties and changes in some natural conditions such as water paths and solute movements (Cameron et al., 1992). Of some concern is nutrient leaching beyond the root zone into ground water, which can potentially lead to ground water pollution (Goss et al., 2010). This is even more critical when recycled wastewater is used for irrigation (Tanji et al., 2007). There are numerous benefits of using recycled water for irrigation, including the low cost (when compared to other sources, particularly in an urban area), consistency of supply (regardless of season, climatic conditions and associated water restrictions), and general consistency of quality. Irrigation of recycled wastewater is also considered as a means for plant fertilization and particularly nutrient supplementation. This approach carries with it a risk of soil and water pollution through excessive wastewater application (Pandey and Srivastava, 2010). Hence, a detailed understanding of soil water conditions is essential for effective utilization of wastewater for irrigation.

This research investigates the relative impact of landscape variation on drainage and solute leaching in a public park containing heterogeneous urban-landscape vegetation that is irrigated with recycled wastewater. For this purpose, two pan lysimeters were designed and installed in two different landscape zones. The field monitoring was undertaken for four seasons; summer (December 2011-February 2012), autumn (March 2012-May 2012), winter (June 2012-August 2012) and spring (September 2012-November 2012).
The outcomes were compared to study the effect of landscape vegetation changes on the behaviour of drained water and nutrient availability in the leachate. Moreover, the volume of drainage was measured for the purpose of developing a detailed soil water budget for the study site. The rate of nutrient removal by leaching was investigated in order to propose an effective urban landscape management regime.

\section{Materials and methods}

\subsection{Study area}

The study was carried out in Veale Gardens within the Adelaide Parklands, South Australia (Fig. 1). Veale Gardens has an area of 9.6 hectares irrigated by recycled wastewater from the Glenelg wastewater treatment plant that is delivered to the Adelaide Parklands through the Glenelg to Adelaide Parklands (GAP) scheme. GAP recycled water is subject to strict quality standards and has been assessed as class A recycled wastewater (Martin et al., 2008).

BOM (2012) report that the long-term (1981-2010) mean annual rainfall for Adelaide is $546.1 \mathrm{~mm}$ while the mean pan evaporation per annum is $1600 \mathrm{~mm}$. Adelaide experiences warm summers (December-February) with a mean temperature of $29.4^{\circ} \mathrm{C}$ in February and fairly cold winters (JuneAugust) with a mean temperature of $7.5^{\circ} \mathrm{C}$ in July.

Veale Gardens contains more than 60 different species, size, and type of landscape trees and shrubs and a broad coverage of Kikuyu turf grasses. Kikuyu is a dominant species in most parks due to its adaptability and invasiveness (Tanji et al., 2007). There were two types of vegetation cover on the site consisting of areas dominated by grasses and areas dominated by a mixture of different species of trees and shrubs accompanied by grasses.

A preliminary soil survey was conducted using EM38 soil mapping that provided rapid field measurement of apparent electrical conductivity (Hossain et al., 2010; Padhi and Misra, 2011). This enabled development of an Electrical Conductivity (EC) soil map through geostatistical analysis in ArcGIS (Rodríguez Martín et al., 2006; Sarangi et al., 2006; Huang et al., 2013; Li et al., 2012). In October 2011, adjacent to each lysimeter, two bores were drilled down to $2 \mathrm{~m}$ and two intact core soil samples $(50 \mathrm{~mm}$ internal diameter) were extracted for soil physical and chemical analysis. Standard methods were followed for sample preparation, packaging, labelling and storage (Handreck and Black, 2002). Based on the soil EC map, soil sample analysis and landscape variation in Veale Gardens, two different zones of low and high EC and two landscape zones of mostly grasses with few trees and shrubs (MG) and mostly trees and shrubs covered with intermittent grasses (MT) were defined. In order to minimize the effect of spatial heterogeneity of soil salinity on the outputs in the initial stage of field work, the experiment was run in the low EC zone (less than $1.2 \mathrm{dS} \mathrm{m}^{-1}$ ). In the low salinity 

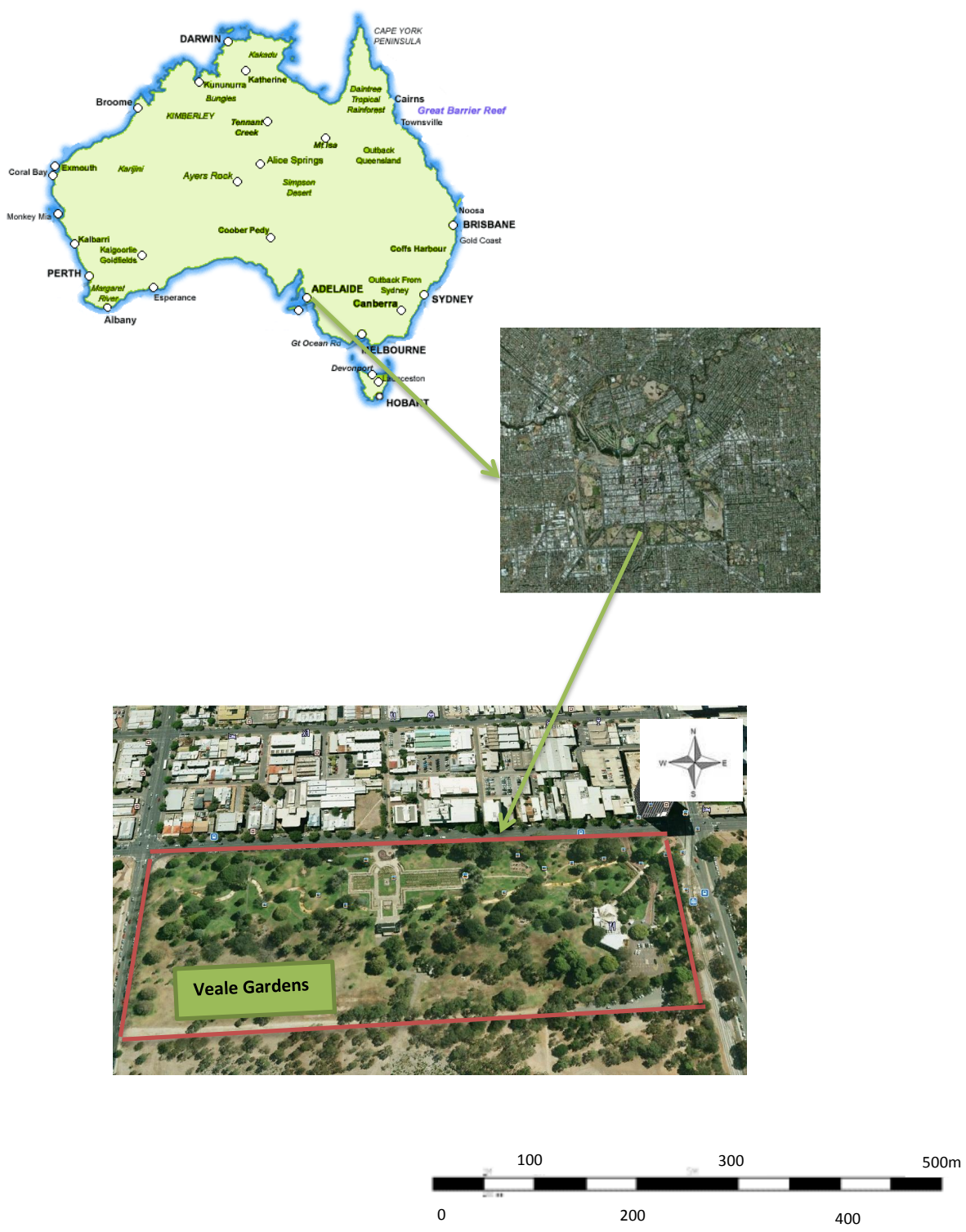

Fig. 1. Veale Gardens in the Adelaide Parklands.

zone, two zero tension pan lysimeters containing undisturbed soils were placed horizontally below ground to study the volume and quality of drainage as a function of landscape variation for 12 months.

\subsection{Field and laboratory measurement of soil and leachate properties}

EM38 soil mapping and spatial analysis produced a soil zoning map for Veale Gardens.

Several previous studies have categorized salinity thresholds from sensitive to tolerant plants.

A soil salinity tolerance level of $1.8 \mathrm{dS} \mathrm{m}^{-1}$ was reported by Handreck and Black (2002) in a very sensitive media for ornamental plants and turf grasses. Miyamoto et al. (2004) selected $1 \mathrm{dS} \mathrm{m}^{-1}$ as a threshold of sensitivity for landscape plants. Stevens et al. (2009) selected $1.3 \mathrm{dS} \mathrm{m}^{-1}$ as a moderate sensitive threshold for irrigation of amenity horticulture with recycled water. Martin et al. (2008) categorized the plant species in the Adelaide Parklands according to various soil salinity tolerance ranges. Considering a salinity tolerance range of $0.8-1.6 \mathrm{dS} \mathrm{m}^{-1}$ for most of the 60 different species of trees, shrubs and turf grasses in Veale Gardens (Martin et al., 2008), a soil salinity threshold of $1.2 \mathrm{dS} \mathrm{m}^{-1}$ was adopted for Veale Gardens. Two different zones of low and high EC are illustrated in Fig. 3. Two positions in the low EC zone (less than $1.2 \mathrm{dS} \mathrm{m}^{-1}$ ) were marked in the field and later tested by a service locator company to ensure there was no conflict with existing assets and underground services, 
particularly irrigation pipes. Soil samples were taken from four bores immediately adjacent to the pan lysimeters.

Drainage water quality and nutrient availability were analysed for each season for certain chemical characteristics including $\mathrm{pH}$, EC, sodium adsorption ratio (SAR), Total Dissolved Solids (TDS), potassium, nitrite, nitrate, total nitrogen, total phosphorus, and ionic balance. Soil pH was monitored with an automated system (PC Titrate) using $\mathrm{pH} 4.5$ for indicating the total alkalinity end-point. Soil salinity and TDS were determined in an aqueous extract of a $1: 5$ soilwater suspension at $25^{\circ} \mathrm{C}$ using an EC meter. Total phosphorus was measured using a discrete analyser. Nitrate was reduced to nitrite by way of a cadmium reduction column followed by quantification by the discrete analyser. Nitrite was determined separately by direct colorimetry. Total $\mathrm{N}$ was analysed using a traditional Kjeldahl digestion followed by determination by the discrete analyser. The ionic balance was calculated based on the major anions and cations. The major anions were determined using the PC Titrate and discrete analyser. Major cations were measured using an inductively coupled plasma atomic emission spectroscopy (National Environment Protection (NEPM) - Assessment of Site Contamination, 1999).

The importance of macronutrients $(\mathrm{N}, \mathrm{P}$ and $\mathrm{K})$ is due to their fundamental role in plant functionality. Nitrogen is a component of protein and enzymes and controls almost all biological processes (Arauzo et al., 2010; Rafizul and Alamgir, 2012). Phosphorus is responsible for energy transfer in the plant, plant development, and photosynthesis (Djodjic et al., 2000). Potassium regulates the water usage of plants and their resistance to diseases (Kolahchi and Jalali, 2007). The SAR measures the ratio of sodium to calcium and magnesium ions and can be used to evaluate the effect of irrigation on soil structure (Goatley, 2011). Ionic balance represents the characteristics of the water in terms of principal dissolved salts. The required nutrients for landscape plants vary widely due to the broad numbers of species of trees, shrubs and turf grasses. For instance, turf grasses need a large amount of nitrogen for green growth while most flowering plants need more potassium and phosphorus (Tanji et al., 2007).

\subsection{Zero-tension pan lysimeter design and installation}

A field investigation was employed to study the quantity and quality of drainage water using zero-tension pan (also known as equilibrium-tension) lysimeters. This was due to the advantages of pan lysimeters compared to other methods, including the low complexity of design, reduced disturbance of the soil during installation, and simple and cheap operation (Zhu et al., 2002). The zero-tension lysimeter is a passive sampler in a pan shape, without large side walls, that freely collects the drained water, measuring drainage volume and solute leaching simultaneously below an undisturbed soil column (Weihermuller et al., 2007; Robison et al., 2004; Zhu et al., 2002). It minimizes the surrounding matric potential fluctuations and potential bypass flow resulting in the conservancy of natural and regular percolation patterns if sprinkler irrigation is uniformly applied in an area larger than the lysimeter area (Lehr et al., 2005).

The lysimeter is typically placed under the ground either at a shallow or deep depth, depending on the effective root zone of the plant (Donn and Barron, 2012; Barron and Donn, 2010). The fill material in the tray has a substantial impact on the water potential gradient and water bypass (Weihermuller et al., 2007). The main sources of errors in pan lysimeters derive from diversion in water flow around the lysimeter as well as the complexity of installation.

The method of installation of the zero-tension lysimeter involved the excavation of a trench with a backhoe down to $150 \mathrm{~cm}$ depth which is mostly below the effective root zone of the plants (Fig. 2a). A small cavity of dimensions $120 \mathrm{~cm} \times 55 \mathrm{~cm} \times 30 \mathrm{~cm}$ was excavated in the long side wall of the trench with a horizontal distance of $100 \mathrm{~cm}$ from the edge of the trench (Fig. 2b). The cavity was precisely levelled in all five walls to prevent adding tension to the system (Fig. 2c). A galvanized metal tray of size $120 \mathrm{~cm} \times 55 \mathrm{~cm}$ with geotextile on top (Fig. 2d) was precisely jacked up and fitted to the upper wall of the cavity in order to adequately maintain the capillary connection of the tray and above lying soil (Fig. 2e). The drainage collection bucket was placed at the base of the trench at a depth of $150 \mathrm{~cm}$ and a rigid PVC pipe connected the lysimeter tray to the collection bucket (Fig. 2f). The drained water was collected in the buried bucket through a rigid PVC pipe and two access tubes (Fig. 2g). To complete installation of the lysimeter, a plastic sheet was placed on the long side wall of the trench to protect the cavity from damage and to ensure separation of the undisturbed and disturbed soil (Fig. 2h). The backfilled soil was compacted by a leg rammer in layers to prevent soil subsidence (Fig. 2i).

The leachate was collected in buckets below the drainage compartments and was regularly extracted from the buckets to the flask by a vacuum hand pump. The volume and salinity of collected water in each bucket was measured monthly during the period December 2011-November 2012.

\section{Results and discussion}

\subsection{Soil properties}

Soil samples from four bores adjacent to the lysimeters were tested. The results showed a texture of silty loam from the ground to $100 \mathrm{~cm}$ with a $\mathrm{pH}$ range of 8.0-8.5 and EC less than $1.2 \mathrm{dS} \mathrm{m}^{-1}$ for lysimeter MG. For lysimeter MT, a texture of sandy loam was recorded from the ground to $100 \mathrm{~cm}$ with a $\mathrm{pH}$ range of $8.0-8.8$ and EC less than $0.6 \mathrm{dS} \mathrm{m}^{-1}$. These results are consistent with a previous SA Water Corporation report (Martin et al., 2008). Goatley (2011) indicated that loamy texture is the most ideal soil for most turf 

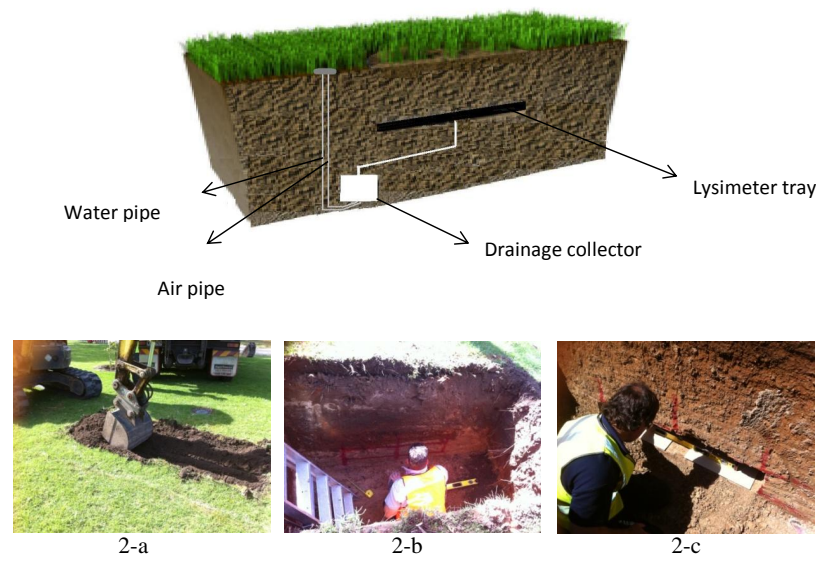

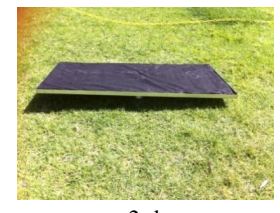

$2-d$
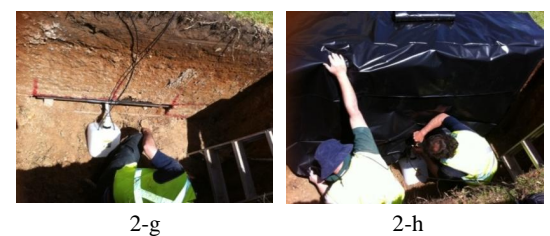

2-h

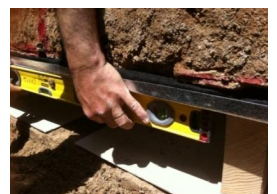

2-e

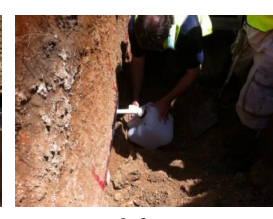

$2-\mathrm{f}$

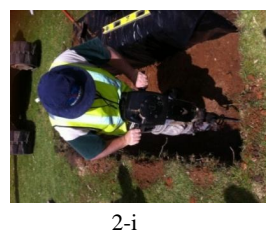

Fig. 2. Pan lysimeter installation, (a) trench excavation, (b) cavity digging, (c) cavity levelling, (d) lysimeter tray, (e) placing the tray, (f) placing the collecting bucket and connect the tray and bucket by a PVC pipe, (g) PVC pipe and access tubes, (h) plastic sheet for protecting the cavity, (i) compacting the backfilled soil.

grasses and landscapes to ensure adequate water accessibility and aeration. Moreover, moderate soil $\mathrm{pH}(6.5-7.5)$ provides a suitable environment for optimum biological activity and nutrient availability, particularly for potassium and phosphorus. It is anticipated that the alkalinity of the soil may result in lower availability of nitrogen and phosphorus but should have no effect on potassium availability (Goatley, 2011).

\subsection{Drainage water quality}

The seasonal volume of drained water in the MG and MT zones for four seasons of summer (December 2011February 2012), autumn (March 2012-May 2012), winter (June 2012-August 2012) and spring (September 2012November 2012) is shown in Table 1. Irrigation data were provided by Adelaide City Council (ACC), who manages Veale Gardens. Rainfall data for the nearest station (Kent Town, Station 023090) were downloaded from the Australian Bureau of Meteorology (BOM). Station 023090 is located on the east side of the city, $2.92 \mathrm{~km}$ from Veale Gardens (http://www.bom.gov.au/climate/data/). It should be noted that the irrigation rate in the MT zone was approximately

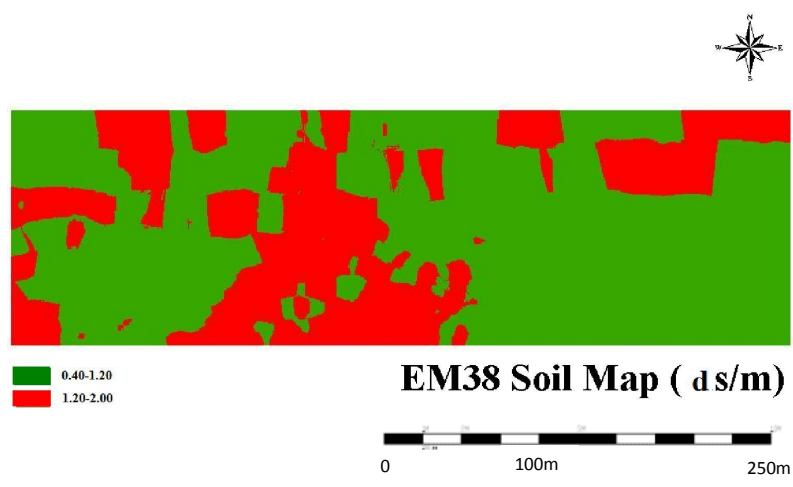

Fig. 3. EM 38 soil map of Veale Gardens showing lysimeter positions.

$20 \%$ higher than in MG zone, except in winter when the irrigation rate was zero in the MG zone but small volumes of irrigation occurred in the MT zone.

A significant difference in drainage rate was noted over the monitoring period in both MG and MT. The differences in lysimeter performance mainly is related to the heterogeneity of vegetation and/or soil characteristics. The variation in landscape plants will have led to differences in evapotranspiration, canopy interception rates and root distribution. Root distributions in the MT zone were denser and deeper due to its mix of trees, shrubs and turf grasses and this will have led to higher moisture uptake rates. These results are consistent with a previous study by Qin et al. (2013) who evaluated the effect of vegetation cover (turf grasses vs. woody ornamental) on drainage rates and nutrient leaching collected from lysimeters. Three different vegetation zones (60\% turf- $40 \%$ ornamental, $75 \%$ turf- $25 \%$ ornamental and $90 \%$ turf- $-10 \%$ ornamental) were investigated. One year of data collection showed that drainage from the $90 \%$ turf zone was higher than the other two zones. They stated that their outcome from measured $\mathrm{N}$ and $\mathrm{P}$ concentrations and loads showed the importance of woody plants in reducing nutrient leaching in urban areas. Wohlfart et al. (2012) found that soil properties were the strongest factor explaining heterogeneity of nutrient loading. However, their findings were for a homogeneous distribution of cropland. Woods et al. (2013) reported a significant change in deep drainage and salt transport in response to changes in soil water balance conditions while at larger scales the changes were more influenced by surface topography. This finding is consistent with the outcomes of Loper et al. (2013) who investigated the effect of vegetation cover types on leaching from early established landscape plots. They reported that different leachate volumes and nutrient leaching were primarily because of differences in root density and shoot biomass resulting in different rates of water availability to the plants. Their results showed a greater leachate volume under woody species than turf grasses during the period when woody ornamentals are still establishing. This is also supported by the findings of Erickson et 
Table 1. Records of drained water from lysimeters and input water (mm).

\begin{tabular}{lrrrr}
\hline Landscape zone & Summer & Autumn & Winter & Spring \\
\hline Seasonal rainfall $(\mathrm{mm})$ & 78.8 & 160 & 262.7 & 53.7 \\
Seasonal irrigation $(\mathrm{mm})$ & 331.11 & 123.8 & 0 & 177.28 \\
Seasonal drainage $(\mathrm{mm})$ & 1.33 & 24.75 & 206 & 95.51 \\
\hline MT zone & & & & \\
Seasonal rainfall $(\mathrm{mm})$ & 78.8 & 160 & 262.7 & 53.7 \\
Seasonal irrigation $(\mathrm{mm})$ & 403.27 & 150.82 & 20 & 215.91 \\
Seasonal drainage $(\mathrm{mm})$ & 0 & 0.022 & 25 & 0.025 \\
\hline
\end{tabular}

al. (2005) who studied the factors affecting nutrient leaching including landscape vegetation and quantity and timing of fertilization. They indicated that mean seasonal drainage of mixed species vegetation was significantly less than monoculture Augustine grass. These results are in line with those of Cattan et al. (2007) and Naeth et al. (2011) who investigated the spatial variability of percolation fluxes in heterogeneous vegetation covers. In terms of soil characteristics, a higher percolation rate and lower available water capacity was expected in the sandy loam soil (MT) compared to the silty loam soil (MG). However, the results indicated a minimal effect on drainage variations from the different soil properties compared to the much stronger influence of vegetation heterogeneity.

A strong positive correlation coefficient of 0.90 was found between drainage rates collected from zones MG and MT. This confirms that there was a similar trend of drainage volume within the four seasons of the study period except for a peak that was observed for the MG zone in October (Fig. 4). It should be noted that the high correlation of the MT and MG zones is influenced by the frequent occurrence of zero values for the MT zone. Thus, both the MT and MG drainage data were normalized based on the mean and standard deviation of the entire group of data. The correlation of normalized MG and MT data showed a positive correlation coefficient of 0.70 .

The minimum drained water was collected in summer in both lysimeters. Also, the maximum input water, aggregated from irrigation and rainfall, was observed in summer which means that plant uptake of water was very high in this season particularly at the MT zone. This indicates that in summer time most input water fulfils plant water needs through evapotranspiration while in winter as a consequence of the dormancy in most plant species, the evapotranspiration rate decreases significantly which results in an increased leachate fraction in winter. These findings confirm a wellknown hypothesis and is consistent with the finding of Loper et al. (2013) who stated that under both vegetation types of woody plants and turf grasses, a large portion of input water (either irrigation or rainfall) was retained as soil moisture or subject to ET rather than drainage loss.

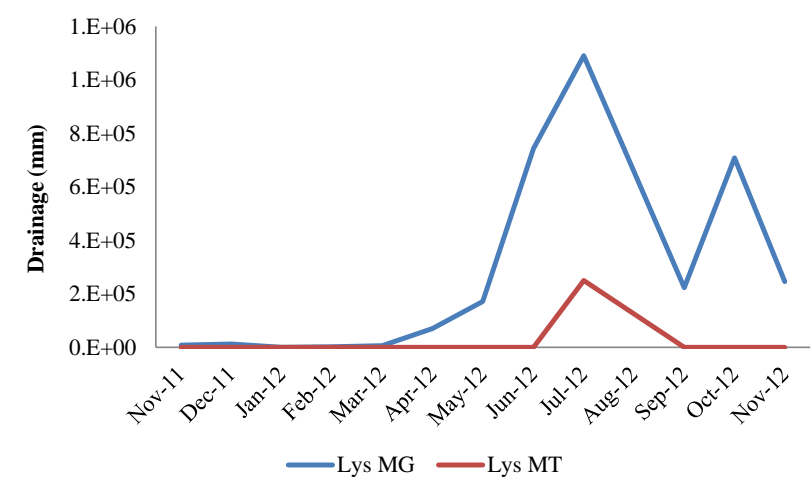

Fig. 4. Monthly variation of drainage in MG and MT zones. * Potassium, nitrite, nitrate, TDS, total $\mathrm{N}$ and $\mathrm{P}$ are in $\mathrm{mg} \mathrm{L}^{-1}$ and $\mathrm{EC}$ is $\mathrm{dS} \mathrm{m}{ }^{-1}$.

\subsection{Drainage water quality}

The differences in drainage rates associated with variation in vegetation landscape zones lead to differences in leachate quality. The electrical conductivity of each water sample was measured using an EC meter to quantify the salinity of solute leaching within the study period. Every month, two samples were collected and the EC value was taken as the average of three EC readings (Table 2).

A comparison of seasonal salinity for zones MG and MT indicated a strong positive correlation $(R=0.97)$ with the lowest salinity in autumn for both lysimeters. The unavailable value of drainage salinity for the MT zone in summer was predicted using linear regression. The predicted value was calculated of $3.06 \mathrm{dS} \mathrm{m}^{-1}$. A new comparison of seasonal drainage salinities between the MT and MG zones using the predicted value for the MT zone in summer showed a very strong positive correlation $(R=0.995)$. No correlation was found between seasonal drainage volume and seasonal salinity in either lysimeter.

The drained water samples were sent to a NATA accredited laboratory (National Association of Testing Authorities, Australia) for water quality analysis. The results of the laboratory tests are shown in Fig. 5 with each column representing the average of two samples and two repeats. For zone MT, the amount of collected leachate was too small to allow an accurate nutrient analysis. However, water salinity was measured in a diluted sample in the MT zone. Figure 5 shows the water quality analysis for the MG zone. Hence, investigation of the variation of all water quality indicators apart from salinity was not possible in MT zone.

The recommended practical long-term trigger concentration levels for Adelaide Parklands irrigation (ANZECC and ARMCANZ, 2000) are $54.5 \mathrm{mg} \mathrm{L}^{-1}$ for Total $\mathrm{N}, 6.8 \mathrm{mg} \mathrm{L}^{-1}$ for Total $\mathrm{P}$ and $29.5 \mathrm{mg} \mathrm{L}^{-1}$ for $\mathrm{K}$. From a comparison of the results in Fig. 5 with these trigger values, it can be concluded that there is little risk of nutrient ( $\mathrm{N}, \mathrm{P}$ and $\mathrm{K}$ ) build-up or nutrient contamination of ground or surface waters. These 


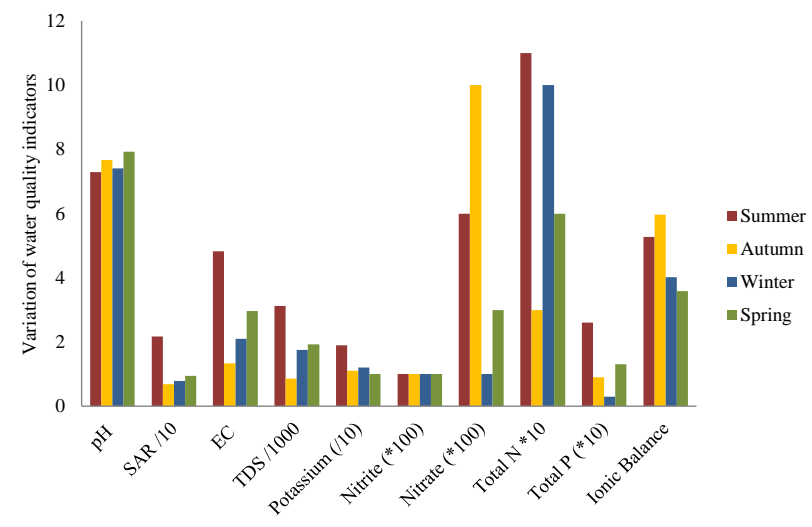

Fig. 5. Seasonal variation of water quality indicators in zone MG. *Potassium, nitrite, nitrate, TDS, total $\mathrm{N}$ and $\mathrm{P}$ are in grams.

Table 2. Seasonal salinity of drained water from two lysimeters.

\begin{tabular}{lrrrr}
\hline Salinity $\left(\mathrm{dS} \mathrm{m}^{-1}\right)$ & Summer & Autumn & Winter & Spring \\
\hline Lys MG & 4.82 & 1.33 & 2.1 & 2.96 \\
Lys MT & NA & 0.85 & 1.14 & 1.91 \\
\hline
\end{tabular}

* NA (not available).

results are consistent with findings of a previous SA Water Corporation study (Martin et al., 2008).

\subsection{Cumulative nutrients leaching}

The outcomes of other research conducted at the same experimental site confirm that the irrigation application was the optimally matched to the water requirements of mixed landscape vegetation to produce an acceptable level of plant health and aesthetics (Hassanli and Kazemi, 2012; Nouri et al., 2013). Thus, the potential excess nutrient loading cannot result from over-irrigation.

The cumulative nutrient loadings $(\mathrm{g})$ were calculated using nutrient loading rates $\left(\mathrm{mg} \mathrm{L}^{-1}\right)$ in a total volume of drained water in a season (L). The results showed the highest nutrient loadings were in either winter or spring (Fig. 6). The sources of drained water were rainfall in all four seasons and recycled wastewater in spring, summer and autumn. Therefore irrigation should not have influenced nutrient loading to the ground water during the winter season. For the rest of the year, the main source of the total input water was recycled wastewater applied by irrigation. However, the measured loading rates were less than long-term safe trigger levels for nutrients. The seasonal variation of drainage quality indicators in Veale Gardens is presented in Table 3. These results will be useful for park management, particularly for formulating fertilization schedules.

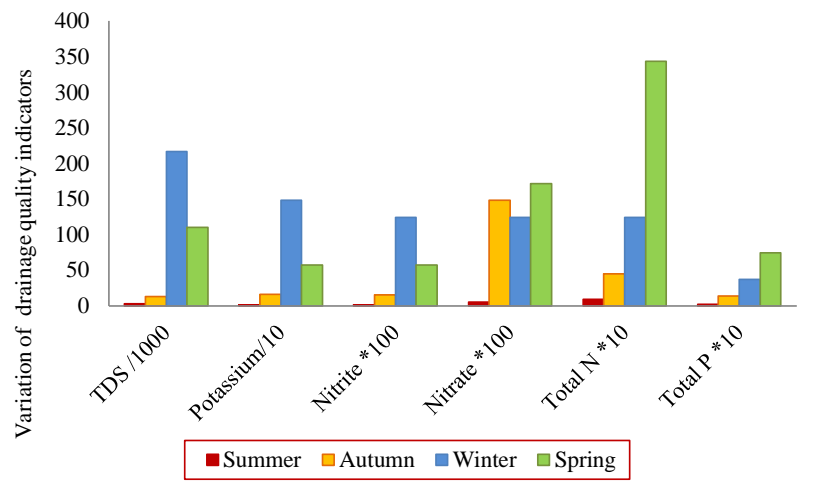

Fig. 6. Seasonal water quality indicators through cumulative drainage.

Table 3. Seasonal variation of drainage quality indicators in Veale Gardens $\left(\mathrm{kg} \mathrm{ha}^{-1}\right)$.

\begin{tabular}{lrrrr}
\hline Drained water characteristics & Summer & Autumn & Winter & Spring \\
\hline TDS & 41.7 & 213.8 & 3605.0 & 1833.6 \\
Potassium & 0.2533 & 2.7225 & 24.7197 & 9.5499 \\
Nitrite & 0.0002 & 0.0025 & 0.0207 & 0.0095 \\
Nitrate & 0.0008 & 0.0247 & 0.0207 & 0.0286 \\
Total N & 0.0147 & 0.0742 & 0.2067 & 0.5730 \\
Total P & 0.0035 & 0.0223 & 0.0618 & 0.1241 \\
\hline
\end{tabular}

\section{Conclusions}

This study has examined the variation of drainage quantity and quality in a heterogeneous urban vegetation environment. Differences in vegetation landscape cover lead to differences in evapotranspiration rates, canopy interception losses, as well as depth, density and distribution of vegetation roots. This is the cause of the higher drainage collection rates in the low vegetation cover (MG) zone compared to the high vegetation cover in the MT zone, which contained dense trees and shrubs and intermittent turf grasses.

Considering results of soil physical analysis indicated a minimal effect of differences of soil properties compared to the much stronger influence of vegetation heterogeneity on drainage variations.

However, investigation of the seasonal variation in drained water quantity showed similar trends in both lysimeters with the highest drainage rate in winter time. This trend is despite the maximum rate of input water which was reported in summer. As expected, in summer most input water fulfils plant water needs through evapotranspiration while in winter as a consequence of dormancy in most plants, the evapotranspiration rate decreases markedly, which results in a higher leachate fraction in winter. Interestingly, there was no relation between seasonal drained water volume and seasonal salinity rates in either of the lysimeters. 
The input water from irrigation and rainfall not used by plants and passed through the root zone may carry some nutrients into the ground water. This could potentially be a matter of concern when recycled wastewater is a main source of irrigation. In Veale Gardens, irrigation with recycled wastewater did not occur in the winter season in the MG zone while the highest concentrations of most analysed nutrients were also recorded during winter. Even so, the recommended Australian nutrient trigger level for solute leaching confirmed that using recycled wastewater presented no increased risk of nutrient ( $\mathrm{N}, \mathrm{P}$ and $\mathrm{K}$ ) build-up or contamination of ground or surface waters compared to using conventional water sources for irrigation.

Acknowledgements. This study was funded by the SA Water Corporation through Research Grant SW100201. The researchers are also grateful to staff at SA Water and particularly to Ms. Karen Rouse. We also appreciate the support of Adelaide City Council and particularly Mr. Kent Williams, Mr. Adam Gunn and all the horticulturists and gardeners working at Veale Gardens. The researchers also acknowledge the support of the Goyder Institute for Water Research. We also thank the Australian Bureau of Meteorology for providing meteorological data. Finally, we are very grateful for the assistance of Dr Sattar Chavoshi and technical officers in the School of Natural and Built Environments at the University of South Australia. We also appreciate the advice of Professor Chris Saint, Professor Nanthi Bolan and Dr Fatemeh Kazemi from the University of South Australia and Mr Terry Evans from the University of Adelaide.

Edited by: N. Ursino

\section{References}

ANZECC and ARMCANZ: Australian and New Zealand guidelines for fresh and marine water quality. Australian and New Zealand Environment and Conservation Council and Agriculture and Resource Management Council of Australia and New Zealand, Australian Water Association, 2000.

Arauzo, M., Martínez-Bastida, J. J., Valladolid, M., and Díez, J. A.: Field evaluation of Gee Passive Capillary Lysimeters for monitoring drainage in non-gravelly and gravelly alluvial soils: A useful tool to estimate nitrogen leaching from agriculture, Agr. Water Manage., 97, 465-474, doi:10.1016/j.agwat.2009.11.006, 2010.

Barron, O. and Donn, M.: Technical note: an approach to groundwater monitoring in urban catchments, edited by: CSIRO, Perth: CSIRO, 2010.

BOM: Australian Government-Bureau of Meteorology, - Annual Climate Summary, edited by: Centres, C. S., Commonwealth of Australia, 2010.

Cameron, K. C., Smith, N. P., McLay, C. D. A., Fraser, P. M., McPherson, R. J., Harrison, D. F., and Harbottle, P.: Lysimeters without edge flow: an improved design and sampling procedure, Soil Sci. Soc. Am., 56, 1625-1628, 1992.

Cattan, P., Voltz, M., Cabidoche, Y. M., Lacas, J. G., and Sansoulet, J.: Spatial and temporal variations in percolation fluxes in a trop- ical Andosol influenced by banana cropping patterns, J. Hydrol., 335, 157-169, doi:10.1016/j.jhydrol.2006.11.009, 2007.

De Kimpe, C. R. and Morel, J.-L.: Urban Soil Management: A Growing Concern, Soil Sci., 165, 31-40, 2000.

Djodjic, F., Ulén, B., and Bergström, L.: Temporal and spatial variations of phosphorus losses and drainage in a structured clay soil, Water Res., 34, 1687-1695, doi:10.1016/S0043-1354(99)003127, 2000.

Donn, M. and Barron, O.: Water quality in the urban main drains managed by Water Corporation - Research outcomes and implications for land and water management, in: Water Corporation of Western Australia and CSIRO, Perth: CSIRO, 2012.

Erickson, J. E., Cisar, J. L., Snyder, G. H., and Volin, J. C.: Phosphorus and potassium leaching under contrasting residential landscape models established on a sandy soil, Crop Sci., 45, 546-552, doi:10.2135/cropsci2005.0546, 2005.

Goatley, M.: Urban Nutrient Management Handbook, edited by: Hoffman, B. A. and Guinn, L., Virginia Cooperative Extension, 2011.

Goss, M. J., Ehlers, W., and Unc, A.: The role of lysimeters in the development of our understanding of processes in the vadose zone relevant to contamination of groundwater aquifers, Phys. Chem. Earth, 35, 913-926, doi:10.1016/j.pce.2010.06.004, 2010.

Hagedorn, F., Mohn, J., Schleppi, P., and Fluhler, H.: The role of rapid flow paths for nitrogen transformation in a forest soil: A field study with micro suction cups, Soil Sci. Soc. Am. J., 63, 1915-1923, 1999.

Handreck, K. A. and Black, N. D.: Growing Media for Ornamental Plants and Turf, UNSW Press, Australia, 560 pp., 2002.

Hangen, E., Gerke, H. H., Schaaf, W., and Hüttl, R. F.: Assessment of preferential flow processes in a forest-reclaimed lignitic mine soil by multicell sampling of drainage water and three tracers, $\mathbf{J}$ Hydrol., 303, 16-37, doi:10.1016/j.jhydrol.2004.07.009, 2005.

Hassanli, A. M. and Kazemi, F.: An Investigation into the Tolerance and Sensitivity of the Adelaide Parklands' Landscape Plants to the Glenelg Recycled Wastewater, University of South Australia, Division of IT, Engineering and the Environment, 2012.

Hossain, M. B., Lamb, D. W., Lockwood, P. V., and Frazier, P.: EM38 for volumetric soil water content estimation in the rootzone of deep vertosol soils, Comput. Electron. Agr., 74, 100-109, doi:10.1016/j.compag.2010.07.003, 2010.

Huang, L., Wang, H., Li, Y., and Lu, S.: Spatial distribution and risk assessment of phosphorus loss potential in urban-suburban soil of Lishui, China, CATENA, 100, 42-49, doi:10.1016/j.catena.2012.08.011, 2013.

Jabro, J. D., Kim, Y., Evans, R. G., Iversen, W. M., and Stevens, W. B.: Passive capillary sampler for measuring soil water drainage and flux in the vadose zone: Design, performance and enhancement, Appl. Eng. Agr., 24, 439-446, 2008.

Jim, C. Y.: Urban soil characteristics and limitations for landscape planting in Hong Kong, Landscape Urban Plan., 40, 235-249, doi:10.1016/S0169-2046(97)00117-5, 1998.

Jim, C. Y. and Chen, W. Y.: Pattern and divergence of tree communities in Taipei's main urban green spaces, Landscape and Urban Planning, 84, 312-323, doi:10.1016/j.landurbplan.2007.09.001, 2008.

Kolahchi, Z. and Jalali, M.: Effect of water quality on the leaching of potassium from sandy soil, J. Arid Environ., 68, 624-639, doi:10.1016/j.jaridenv.2006.06.010, 2007. 
Kosugi, K. and Katsuyama, M.: Controlled-Suction Period Lysimeter for Measuring Vertical Water Flux and Convective Chemical Fluxes, Soil Sci. Soc. Am. J., 68, 371-382, doi:10.2136/sssaj2004.3710, 2004.

Lassaletta, L., Romero, E., Billen, G., Garnier, J., García-Gómez, H., and Rovira, J. V.: Spatialized N budgets in a large agricultural Mediterranean watershed: high loading and low transfer, Biogeosciences, 9, 57-70, doi:10.5194/bg-9-57-2012, 2012.

Lehr, J., Keeley, J., Lehr, J., and Kingery, T. B.: Water Encyclopedia: Ground Water, John Wiley \& Sons, Inc., Hoboken, New Jersey, 2005.

Li, H., Shen, W., Zou, C., Jiang, J., Fu, L., and She, G.: Spatio-temporal variability of soil moisture and its effect on vegetation in a desertified aeolian riparian ecotone on the Tibetan Plateau, China, J. Hydrol., 479, 215-225, doi:10.1016/j.jhydrol.2012.12.002, 2012.

Loper, S. J., Shober, A. L., Wiese, C., Denny, G. C., and Stanley, C. D.: Nutrient Leaching during Establishment of Simulated Residential Landscapes, J. Environ. Qual., 42, 260-270, 2013.

Lorenz, K. and Kandeler, E.: Biochemical characterization of urban soil profiles from Stuttgart, Germany, Soil Biol. Biochem., 37, 1373-1385, doi:10.1016/j.soilbio.2004.12.009, 2005.

Martin, R., Thomas, B., Luitjes, K., and White, L.: An adaptive Management Framework for Reuse and Treated Wastewater from the Glenelg WWTP within the Adelaide Park Lands, Final Report, edited by: R.E.M. (rem), Adelaide, 2008.

Moreno-Jiménez, E., Beesley, L., Lepp, N. W., Dickinson, N. M., Hartley, W., and Clemente, R.: Field sampling of soil pore water to evaluate trace element mobility and associated environmental risk, Environ. Poll., 159, 3078-3085, doi:10.1016/j.envpol.2011.04.004, 2011.

Miyamoto, S., Martinez, I., Padilla, M., Portillo, A., and Ornelas, D.: Landscape Plant Lists for Salt Tolerance Assessment, by Agricultural Research and Extension Center of El Paso, Texas Agricultural Experiment Station, Texas A\&M University System; report, 12 pp., 2004.

Naeth, M. A., Chanasyk, D. S., and Burgers, T. D.: Vegetation and soil water interactions on a tailings sand storage facility in the athabasca oil sands region of Alberta Canada, Phys. Chem. Earth, 36, 19-30, doi:10.1016/j.pce.2010.10.003, 2011.

National Environment Protection (NEPM): Assessment of Site Contamination: Guideline on Laboratory Analysis of Potentially Contaminated Soils, edited by: Schedule, B., Australia: Environment Protection and Heritage Council (EPHC), 1999.

Nouri, H., Beecham, S., Kazemi, F., and Hassanli, A.M.: A review of ET measurement techniques for estimating the water requirements of urban landscape vegetation. Urban Water J., 10, 247$259,2012$.

Nouri, H., Beecham, S., Kazemi, F., and Hassanli, A.: Water Requirements of Urban Landscape Plants: A Comparison of Three Factor-based Approaches, J. Ecol. Eng., Elsevier, 57, 276-284, 2013.

Padhi, J. and Misra, R. K.: Sensitivity of EM38 in determining soil water distribution in an irrigated wheat field, Soil Till. Res., 117, 93-102, doi:10.1016/j.still.2011.09.003, 2011.

Pandey, A. and Srivastava, R. K.: Role of dendropower in wastewater treatment and sustaining economy, J. Clean. Prod., 18, 11131117, doi:10.1016/j.jclepro.2010.02.026, 2010.
Parizek, R. R. and Lane, B. E.: Soil-water sampling using pan and deep pressure-vacuum lysimeters, J. Hydrol., 11, 1-21, doi:10.1016/0022-1694(70)90111-3, 1970.

Peters, A. and Durner, W.: Large zero-tension plate lysimeters for soil water and solute collection in undisturbed soils, Hydrol. Earth Syst. Sci., 13, 1671-1683, doi:10.5194/hess-13-16712009, 2009.

Qin, Z., Shober, A. L., Beeson, R. C., and Wiese, C.: Nutrient leaching from Mixed Species Florida Residential Landscapes. J. Environ. Qual., 42, 1534-1544, doi:10.2134/jeq2013.04.0126, 2013.

Rafizul, I. M. and Alamgir, M.: Characterization and tropical seasonal variation of leachate: Results from landfill lysimeter studied, Waste Management, 32, 2080-2095, doi:10.1016/j.wasman.2012.01.020, 2012.

Robison, W. L., Stone, E. L., and Hamilton, T. F.: Large Plate Lysimeter Leachate Collection Efficiency for Water Being Transported From Soil to Ground Water, Soil Sci., 169, 758-764, 2004.

Rodríguez Martín, J. A., Arias, M. L., and Grau Corbí, J. M.: Heavy metals contents in agricultural topsoils in the Ebro basin (Spain). Application of the multivariate geoestatistical methods to study spatial variations, Environ. Poll., 144, 1001-1012, doi:10.1016/j.envpol.2006.01.045, 2006.

Rosen, C. J., Bierman, P. M., and Eliason, R. D.: Soil Test Interpretations and Fertilizer Management for Lawns, Turf, Gardens, and Landscape Plants, edited by: a.C. Department of Soil, University of Minnesota, 2008.

Sarangi, A., Madramootoo, C. A., and Enright, P.: Comparison of Spatial Variability Techniques for Runoff Estimation from a Canadian Watershed, Biosyst. Eng., 95, 295-308, doi:10.1016/j.biosystemseng.2006.06.002, 2006.

Stevens, D., Smolenaars, S., and Kelly, J.: Irrigation of Amenity Horticulture with Recycled Water, Arris Pty Ltd.: Urrbrae, South Australia, 2009.

Tanji, K., Grattan, S., Grieve, C., Harivandi, A., Rollins, L., Shaw, D., Sheikh, B., and Wu, L.: Salt Management Guide for Landscape Irrigation with Recycled Water in Coastal Southern California - A Comprehensive Literature Review, edited by: Southern California Salinity Coalition (SCSC) and National Water Research Institute (NWRI), 2007.

Weihermuller, L., Siemens, J., Deurer, M., Knoblauch, S., Rupp, H., Gottlein, A., and Putz, T.: In Situ Soil Water Extraction: A Review, J. Environ. Qual., 36, 1735-1748, doi:10.2134/jeq2007.0218, 2007.

Wohlfart, T., Exbrayat, J.-F., Schelde, K., Christen, B., Dalgaard, T., Frede, H.-G., and Breuer, L.: Spatial distribution of soils determines export of nitrogen and dissolved organic carbon from an intensively managed agricultural landscape, Biogeosciences, 9, 4513-4525, doi:10.5194/bg-9-4513-2012, 2012.

Woods, S. A., Dyck, M. F., and Kachanoski, R. G.: Spatial and temporal variability of soil horizons and long-term solute transport under semi-arid conditions, Can. J. Soil Sci., 93, 173-191, 2013.

Yoo, C.: Sampling of soil moisture fields and related errors: implications to the optimal sampling design, Adv. Water Res., 24, 521-530, doi:10.1016/s0309-1708(00)00033-6, 2001.

Zhu, Y., Fox, R. H., and Toth, J. D.: Leachate Collection Efficiency of Zero-tension Pan and Passive Capillary Fiberglass Wick Lysimeters, Soil Sci. Soc. Am. J., 66, 37-43, doi:10.2136/sssaj2002.0037, 2002. 